\title{
An Exploratory Study of Apparel Dress Model Technology on European Web
}

\author{
James Lawler \\ Pace University, \\ New York City, USA
}

¡lawler@pace.edu

\author{
Pascale Vandepeutte \\ University of Mons-Hainaut, \\ Mons, Belgium
}

\author{
Anthony Joseph \\ Pace University, New York City, USA
}

ajoseph2@pace.edu

\begin{abstract}
This study explores the criticality of design that contributes to discernable differential in the experiences of goal-focused shoppers on European dress model Web sites. Focused on the apparel industry in the European Union, the study examines accessibility and convenience, availability of information, lack of sociality, media richness, and product selection, extending the technology acceptance model (TAM). The findings of the study suggest that fundamental functionality is more helpful than advanced richness or sophistication of technology on dress model sites. The study was conducted as a laboratory experiment with adult students at a leading European business university, in comparison to and in continuance of an earlier project on American Web sites with American students at a major university in the United States, in which the findings on media richness were replicated in this study. These findings will benefit European marketing practitioners and researchers who review the impact of dress model technology on shopping Web sites.
\end{abstract}

Keywords: apparel industry, business-to-consumer (B2C), dress model technology, e-Business, European Union, and goal-focused shopping

\section{Dedication}

The authors dedicate this study to Pol Thiry (1940 - 2007), who was Professor of the University of Mons-Hainaut, Mons, Belgium, and whose diligence and exceptional friendship helped in initiating a productive relationship in research with Pace University, United States of America, that continues undiminished with further international studies.

Material published as part of this publication, either on-line or in print, is copyrighted by the Informing Science Institute. Permission to make digital or paper copy of part or all of these works for personal or classroom use is granted without fee provided that the copies are not made or distributed for profit or commercial advantage AND that copies 1) bear this notice in full and 2) give the full citation on the first page. It is permissible to abstract these works so long as credit is given. To copy in all other cases or to republish or to post on a server or to redistribute to lists requires specific permission and payment of a fee. Contact Publisher@InformingScience.org to request redistribution permission.

\section{Introduction}

Electronic business (e-Business) continues to advance in countries of the European Union. Indices display activity adoption of e-Business as generally high, as indicated in Figure 1. 


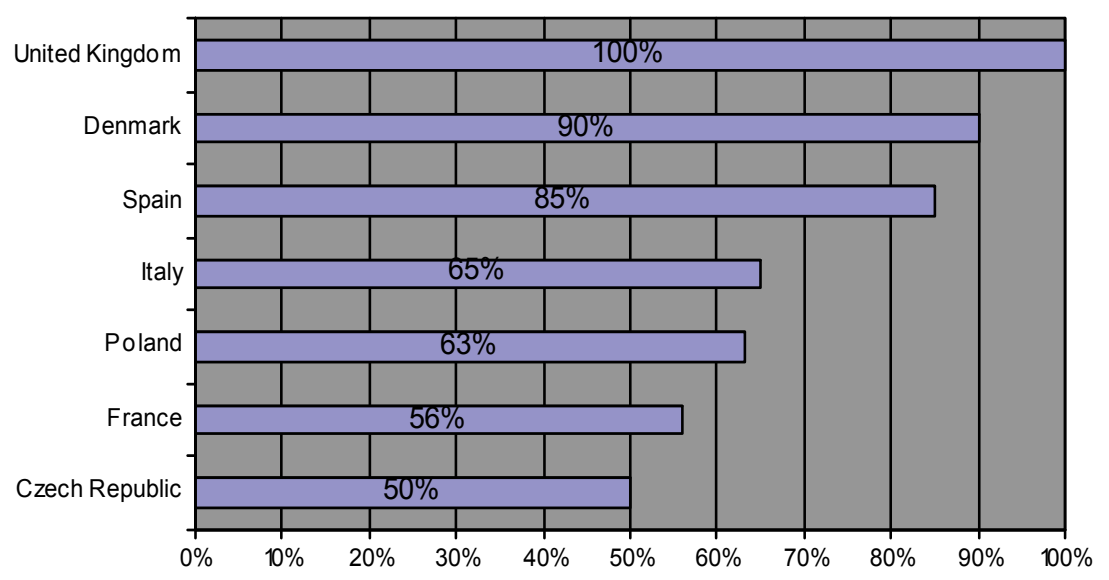

Figure 1: European Union e-Business Adoption Index

(Adoption as a Percentage of Firms in e-Business)

Source: European Commission (2005a)

Actual adoption of e-Business infrastructure is also largely high, but different by the countries, as indicated in Figure 2.

\begin{tabular}{|l|c|c|c|c|c|}
\hline Countries & $\begin{array}{c}\text { Basic } \\
\text { e-Business In- } \\
\text { frastructure }\end{array}$ & $\begin{array}{c}\text { Business } \\
\text { to } \\
\text { Consumer } \\
\text { (B2C) }\end{array}$ & $\begin{array}{c}\text { Business } \\
\text { to } \\
\text { Business } \\
\text { (B2B) }\end{array}$ & $\begin{array}{c}\text { Business } \\
\text { to } \\
\text { Employee } \\
\text { (B2E) }\end{array}$ & Index \\
\hline Denmark & $98 \%$ & $97 \%$ & $96 \%$ & $94 \%$ & $100 \%$ \\
\hline United Kingdom & 100 & 100 & 100 & 80 & 98 \\
\hline France & 81 & 68 & 83 & 100 & 86 \\
\hline Spain & 80 & 75 & 99 & 72 & 84 \\
\hline Czech Republic & 77 & 51 & 64 & 71 & 69 \\
\hline Poland & 70 & 51 & 65 & 71 & 67 \\
\hline Italy & 70 & 63 & 50 & 65 & 65 \\
\hline
\end{tabular}

Figure 2: European Union e-Business Infrastructure Index

(Adoption as a Percentage of Firms in e-Business)

Source: European Commission (2005b) [Adapted]

Estimates indicate that $17 \%$ of firms in these countries conducted e-Business marketing and sales on the Internet in 2005 (European Commission, 2005b, p. 8). European consumers buying apparel on the e-Business Web are estimated to be 40 million in 2006 and are forecasted to be 73 million in 2009 (Horyn, 2005). Growth of e-Business in the European Union, as in the United States, affords analysis of business-to-consumer (B2C) competitive design that can contribute beneficially to the field.

European apparel firms are as challenged as American firms in having a competitively creative eBusiness design on their sites (Koo, Koh, \& Nam, 2004). They have to be conscious of consumer expectations and perceptions of service, risk, price, product and experience (Jarvenpaa \& Todd, 1997) and fulfillment, promotion and quality (Urban, Carter, Gaskin, \& Mucha, 1986), in differentiating an experience on the sites. Differentiation and innovation in an e-Business design by European firms may give an edge to an apparel Web site. 
Design is defined in terms of style and usability on a Web site. Literature in differentiation indicates factors of perceived ease of use and perceived usefulness from the frequently cited technology acceptance model (TAM) as important in influencing consumers to adopt information technology (Brown, Massey, Montoya-Weiss, \& Burkman, 2002; Davis, 1989; Venkatesh, Morris, Davis G., \& Davis F., 2003), if not enjoy and buy on a Web site (Koufaris, 2002). Usefulness may be defined as the extent to which a consumer perceives a site enhancing a shopping process task, and ease of use may be the extent to which the consumer perceives the site to be free of effort in the process of shopping (Venkatesh \& Davis, 2000). An ideally designed Web process for shoppers is differentiated in ease of use and usefulness of the site. Sites considered easy to search for information may influence less price sensitivity (Lynch \& Ariely, 1998). Literature indicates economic benefits to firms from factors that facilitate shopping tasks (Saeed, Hwang, \& Grover, 2003).

The focus of this study is to examine the importance of design factors that can contribute to a differential in the experiences of European goal-focused shoppers on European Union apparel dress model sites.

\section{Literature Review}

Though guidelines in the design and differentiation of Web sites have been defined in European and American literature (Cronin, 1995; Lynch \& Horton, 1999; Nielsen, 2002), apparel sites do not always achieve desired impact, due to design and also to perceptions of product, price, risk, service, and quality. Consumers continue to abandon shopping carts, though their goal may be to buy on a site. They form flash impressions of sites in $1 / 20^{\text {th }}$ of a second (Caudron, 2006) and search for products, if not prices, on competitor sites.

Differentiation in the design of apparel sites for especially goal-focused shoppers on the Web is examined in our study of sites in the United States (Lawler \& Joseph, 2006). In that study goal focusing is indicated to be deliberate, efficient, fast, rational and task-focused shopping (Hoffman $\&$ Novak, 1996). Goal-focused shoppers are frequently independent of the help of on-line sales and service staff and are indicated to have a definite objective to buy already identified products on the Web without the help of staff (Moe \& Fader, 2001). Though not all apparel consumers are goal-focused shoppers, these shoppers are good practical subjects from which to study an experience of shopping on the Web that they may enjoy less than those who are not goal-focused shoppers. Differentiation of the experience may be more important in immediately satisfying the requirements of goal-focused shoppers who may not otherwise be excited about shopping in stores or on the Web.

To differentiate the experience of shopping on the Web, and to induce buying, firms have designed dress models or dressing rooms on their sites. Examples include www.bonprix-shop.be in Europe (Ewing, 2006) and www.landsend.com in the United States. These designs are enabled by broadband and digital imaging (Spector, 2005). Mini-systems that function in browser native systems are enabling information on products to instantly pop up when a consumer rolls a mouse over graphic product representations on Web sites (Levinson, 2006). Richer systems are facilitated by Macromedia Flash and new Asynchronous JavaScript and XML (Ajax) technologies (Jones, 2006) that limit page reloading of sites.

These designs distinguish experiences of Web shopping. Further initiatives of the firms include marketing on Web boutiques that are on simulation and social networking sites (Hemp, 2006; Jana, 2006). Marketing on www.secondlife.com is an example of the initiatives.

Media richness of dress model and dressing room technologies may impact consumer experience (Klein, 2003). Interactivity (Li, Daugherty, \& Biocca, 2001) and sensory information with these technologies may impact the consumer decision to buy from the sites (Fiore \& Jin, 2003). How- 
ever, the literature on the impact of richness on the intention of goal-focused shoppers to buy apparel from advanced technological dress model sites, in contrast to the impact of non-richness factors, continues to be inconclusive.

The dress model sites have to be evaluated for full functionality, as an experience of media richness is essentially inferior to experiences in actual stores (Biocca, 1997). In our earlier study of sites in the United States, we explored from the literature non-richness factors of accessibility and convenience - ease in effort in buying products sold on sites, availability of information - organized and searchable specifications on products, lack of sociality - fulfillment in buying products with or without on-line sales help, and product selection - sufficiency in inventory of products sold on sites (Wolfinbarger \& Gilly, 2001). These factors, further explained in the earlier study, can give goal-focused shoppers control and freedom to buy on the Web.

Accessibility and convenience in buying may not be apparent in dress model rooms on the Web that do not have the sensation and touch of apparel displayed in stores. Availability of information on apparel products may not be discernable on sites that do not have intuitive navigation or sufficient search. Lack of sociality may not be evident on sites that do not have optional on-line incident interaction with staff perceived as effective by shoppers (Patton, 2006).

Though lack of sociality on sites without on-line staff is a desirable factor in the independence of goal-focused shoppers (Moe \& Fader, 2001), these shoppers may have more information or less information on the sites than is helpful for them in buying apparel products (Fisher, 1999). Studies indicate that clients of systems are satisfied when outcomes match their expectations, goals and requirements (Applegate, 1993) that are personally relevant to them (Celsi \& Olson, 1988). To be satisfied in shopping, fiercely independent goal-focused shoppers may have to inevitably interact with on-line sales or service staff if the sites are not immediately satisfying to their needs. They may interact with the staff through low touch options, such as chat or e-mail, or high touch options on the sites, such as desktop sharing or video conferencing (Chen, Chen \& Kazman, 2007). The lack of sociality in enabling fulfillment for goal-focused shoppers to shop without staff or optionally with staff as needed by these shoppers is a good and important factor in Web design.

The final non-richness factor of product selection may not be discernable on the sites that do not have equivalent or sufficient inventory of products sold in the stores.

Evaluation has to be for functionality (Lightner, 2004) that is not immediately inherent in richness of technologies.

This study expands an examination of these factors of accessibility and convenience, availability of information, lack of sociality and selection, and especially of media richness, from our study of sites in the United States to those in the European Union. The factors extend the technology acceptance model to form increased control and freedom of the shoppers. The scope of the importance of richness of technologies on the sites is not clear in European literature on dress model sites, and this paper studies the importance of richness of technologies relative to non-richness for goal-focused shoppers on European Union Web sites.

The focus of this study is to therefore examine the importance of design factors that can contribute to a differential in the experiences of European goal-focused shoppers on European Union dress model sites. The study is focused on factors that facilitate the experience of goal-focused shoppers on dress model sites, especially richness of technologies, and not on risk, price or product quality factors. This study in its initial findings helps in exploration of design factors that impact intentions to buy of European goal-focused shoppers on European dress model sites, at a time when operating margins in the apparel industry are under pressure (Baudouin \& Kara, 2006). 


\section{Methodology}

The research experiment of the study consisted of an analysis of a sample of on-line European apparel firms. In stage 1 of the analysis, 150 apparel sites were chosen by 40 senior postgraduate, graduate and undergraduate business students in the spring 2005 semester, as a project in an $e$ Business Concepts and Applications course, a basic program of study, at the University of MonsHainaut in Belgium. The students chose the sites based on consumer commonality on the Western European Web. From the 150 sites, we, who were the instructors of the course, chose 10 dress model and picture sites for analysis, based on diversity of Dutch, English, French, German and Spanish languages on the sites, earlier frequency of choice, and functionality of e-Business and customer relationship management (CRM). In stage 2 these sites, which are abound, bonprixshop, bonaparte, cyrillus, haburi, laredoute, mangoshop, mexx, somewhere and 3suisses, were analyzed anonymously and independently in a continuance of the project by 27 new scholar and senior undergraduate students, in an advanced program of study. The sites were analyzed as an extra credit project in the mid-spring 2006 semester of the program.

The 27 students who analyzed the 10 sites were adequately fluent in the diverse languages on the sites and were knowledgeable consumer subjects. Average age of all students was 22.44 years with females aged 22.79 years and males 22.08 years, they were employed part-time $(75 \%)$ in local industry, and they were $52 \%$ female $(n=14)$ and $48 \%$ male $(n=13)$. They were frequent and knowledgeable consumers on the Web (38 hours a week), which was higher than other population segments of the European Union (Peterson, 2006) and of the United States, through broadband and local networking technologies installed in a laboratory of the university. Students were chosen as subjects by the instructors in order to gain control of the experiment, have the experiment completed in preliminary findings in the laboratory in a faster and simple manner (Bergadaa $\&$ Hebali, 2001), and facilitate and extend the experiment for further analysis by later non-student subjects. These students nevertheless were proactive and realistic subjects (Ohmae, 2005) for stage 2 of the analysis of European apparel dress model sites.

The 10 sites were analyzed by the 27 students in stage 2 of the study for design factors helpful in intention to buy apparel on the sites. Each student was allocated a fictitious 1,000 euros to buy casual apparel from one or a number of the sites, on an experimental goal-focused shopping project. The task for the students was to assume the below:

1. You are chosen for a casual dinner interview with a concert promoter for a position of a judge at a beer festival of jazz music in the city square of Mons, Belgium, and you are given by a benefactor 1,000 euros to buy casual apparel from any of the project Web sites, in order to be dressed for the interview;

2. You are to consider the actual casual apparel that you desire to buy for the interview; and

3. You are to analyze each of the Web sites for helpfulness in your goal or intention to buy or not buy the apparel from them, based on accessibility and convenience, availability of information, lack of sociality, media richness and product selection and control and freedom factors already defined both in our course program and on the enclosed instrument of analysis, applying an analysis from $5=$ very helpful in intention to buy to $0=$ not at all helpful, and you are to submit your findings to the instructors by the conclusion of the program.

The sites were analyzed by each of the 27 students in the factors of accessibility and convenience, availability of information, lack of sociality, selection and control and freedom, and in the factor of media richness, which was of greatest interest in the study, and they applied a six-point rating scale of $5=$ very helpful in intention to buy, $4=$ highly helpful, $3=$ frequently helpful, $2=$ help- 
ful, $1=$ somewhat helpful, and $0=$ not at all helpful in the project shopping task. The analysis was done with an instrument prepared in French.

The instrument of study was evaluated for feasibility for the shopping task by two other instructors and three postgraduate students, in an initial experiment in the early semester of stage 2 . From this evaluation, the instructions for the task were edited by the instructors of the program for the actual experiment in the laboratory in mid-semester 2006. The students analyzed the sites in the laboratory of the University of Mons-Hainaut, which was equipped with Dell Pentium machines in a Bell Net Ethernet Microsoft NT high speed network. Each of the sites was evaluated by each of the 27 students, irrespective of non-buying on a site. The students were not encumbered by the experiment and completed the project in the late spring semester 2006.

The experiment of the current study of European Union sites is similar to an earlier study by us of dress model sites in the United States, analyzed by e-Commerce graduate students of Pace University in New York City in 2003 - 2005 (Lawler \& Joseph, 2006).

In stage 3 of the study descriptive statistics were applied by us in fall - winter 2006, in order to analyze the evaluation factors of accessibility and convenience, availability of information, lack of sociality, media richness, product selection, and control and freedom. Means were applied to determine the central tendency of each factor, and standard deviations were applied to determine the variability of each factor about its mean and the relative variability of each factor to each factor in the experiment. Frequency distributions of the factors were generated over the evaluation ratings, in order to furnish a picture of the concentration of the ratings within and across the factors. Finally, a correlation matrix was applied to furnish the relatedness between pairs of evaluation factors and information on the strength and significance of the linear relationship between any dual pairs of factors, with the rule of thumb for the level of the relationship between pairs of factors being $0<\mathrm{r}<0.5$ is a weak, $0.5<\mathrm{r}<0.8$ is a moderate, and $0.8<\mathrm{r}<1.0$ is a strong correlation (DeVore, 1995; McClave \& Sincich, 2006).

\section{Findings}

From a summary of the means, shown in Table 1 and detailed in the Appendix, the factor of media richness was evaluated as less important than the non-richness factors in helpfulness in the intention of the Belgian students to buy on the Web sites. Accessibility and convenience (mean = 3.34), availability of information (3.26), product selection (3.23), control and freedom (3.18) and lack of sociality (3.17) had more relative importance than media richness (2.65), in helpfulness in the intention of the students to buy on the sites. The factor of media richness had the lowest mean of 2.65, and the other factors had at least 3.17, which suggest that richness had the lowest evaluations of any factor. In our earlier study of American Web sites (Lawler \& Joseph, 2006), richness after lack of sociality had the lowest mean of 2.33, which suggested the second lowest evaluations of any factor in that study. Evaluations of media richness of 2.65 by male students and of 2.66 by female students in our current study were essentially the same. Differences in the evaluations of the female and male students for the other factors were higher than 0.01 and as high as 0.18 for the factor of accessibility and convenience. Except for Web sites \#4 and \#9 (Appendix), which had evaluated means of media richness of 2.74 and 3.35, equal or higher than the means of product selection, the means of the factor of richness on the other sites were lower than those of the other factors. These mean ratings were less than 3.00 (frequently helpful). Moreover, half of the sites (\#1, \#5,\#6,\#8 and \#10) had median ratings of media richness of 2 (helpful). 
Table 1: Analysis of Evaluation Factors - Summary

\begin{tabular}{|c|c|c|c|c|c|c|}
\hline & $\begin{array}{c}\text { Accessibility } \\
\text { and Conven- } \\
\text { ience }\end{array}$ & $\begin{array}{c}\text { Availability of } \\
\text { Information }\end{array}$ & $\begin{array}{c}\text { Lack } \\
\text { of } \\
\text { Sociality }\end{array}$ & $\begin{array}{c}\text { Media } \\
\text { Richness }\end{array}$ & $\begin{array}{c}\text { Product } \\
\text { Selection }\end{array}$ & $\begin{array}{c}\text { Control } \\
\text { and } \\
\text { Freedom }\end{array}$ \\
\hline Mean & 3.34 & 3.26 & 3.17 & 2.65 & 3.23 & 3.18 \\
\hline $\begin{array}{c}\text { Standard } \\
\text { Deviation }\end{array}$ & 1.01 & 0.98 & 0.94 & 0.97 & 0.98 & 0.83 \\
\hline $\begin{array}{c}\text { Mean } \\
\text { Male }\end{array}$ & 3.43 & 3.22 & 3.18 & 2.65 & 3.22 & 3.17 \\
\hline $\begin{array}{c}\text { Standard } \\
\text { Deviation } \\
\text { Male }\end{array}$ & 0.88 & 0.87 & 0.88 & 0.96 & 0.87 & 0.73 \\
\hline $\begin{array}{c}\text { Mean } \\
\text { Female }\end{array}$ & 3.25 & 3.29 & 3.15 & 2.66 & 3.25 & 3.19 \\
\hline $\begin{array}{c}\text { Standard } \\
\text { Deviation } \\
\text { Female }\end{array}$ & 1.11 & 1.07 & 1.00 & 0.99 & 1.08 & 0.92 \\
\hline
\end{tabular}

The overall differences in the mean ratings of the factors and for male students and female students were examined in Table 2 under the null hypothesis that there were no significant differences between the means of any two factors. This examination was done using two sample twotailed t-tests with unequal variances. The differences between the mean of media richness and the mean of any of the other five factors were found to be statistically significant at the 0.01 level. For females, the differences in the mean ratings of the other factors were not significant, but for males and overall students the differences in the means of accessibility and convenience and lack of sociality and accessibility and convenience and control and freedom were statistically significant at the 0.05 level. Moreover, for males the difference in the means of accessibility and convenience and product selection was statistically significant.

These findings indicate that media richness is a relatively unimportant evaluation factor for male and female goal-focused shoppers. They show that male and female goal-focused shoppers perceive the other factors of accessibility and convenience, availability of information, lack of sociality, product selection and control and freedom as being relatively more helpful in their on-line shopping, with female shoppers finding the factors equally helpful to them, and male shoppers finding accessibility and convenience to be significantly more helpful than lack of sociality, product selection, or control and freedom.

Table 2: p-Values of Summary of Two Sample t-Tests for Means of Factors

\begin{tabular}{|l|l|l|l|l|l|}
\hline & $\begin{array}{c}\text { Accessibility } \\
\text { and Conven- } \\
\text { ience }\end{array}$ & $\begin{array}{c}\text { Availability of } \\
\text { Information }\end{array}$ & $\begin{array}{c}\text { Lack of So- } \\
\text { ciality }\end{array}$ & $\begin{array}{c}\text { Media Rich- } \\
\text { ness }\end{array}$ & $\begin{array}{c}\text { Product } \\
\text { Selection }\end{array}$ \\
\hline $\begin{array}{l}\text { Availability of } \\
\text { Information }\end{array}$ & 0.340 & & & & \\
\hline $\begin{array}{l}\text { Lack of } \\
\text { Sociality }\end{array}$ & $0.043^{*}$ & 0.283 & & & \\
\hline Media Richness & $0.000^{* *}$ & $0.000^{* *}$ & $0.000^{* *}$ & & \\
\hline $\begin{array}{l}\text { Product } \\
\text { Selection }\end{array}$ & 0.226 & 0.792 & 0.422 & $0.000^{* *}$ & \\
\hline $\begin{array}{l}\text { Control and } \\
\text { Freedom }\end{array}$ & $0.045^{*}$ & 0.320 & 0.885 & $0.000^{* *}$ & 0.479 \\
\hline
\end{tabular}

is where the $p$-value indicates that the differences in means are statistically significant at $p<0.05$ level

${ }^{* *}$ is where the $\mathrm{p}$-value indicates that the differences in means are statistically significant at $\mathrm{p}<0.01$ level 
In a summary of the standard deviations, in the earlier Table 1 and detailed in the Appendix, accessibility and convenience (1.01), availability of information (0.98), lack of sociality (0.94), media richness (0.97), product selection (0.98) and control and freedom (0.83) were generally not consistent to each of the other factors. The factor of media richness along with accessibility and convenience, availability of information and product selection had the highest standard deviations; in our study of the American Web sites media richness (1.46) along with lack of sociality (2.06) had the highest deviations. The factor of media richness in this study had the relative lowest concentration of evaluations about the means with a standard deviation of 0.96 by male students and the second most concentrated evaluations with a deviation of 0.99 by female students. Media richness standard deviations ranged from relative lowest on sites \#1 and \#4 of 0.69 and 0.90 to relative highest on sites $\# 8, \# 9$ and $\# 10$ of $1.15,1.09$ and 1.19 respectively.

The variability of the evaluations about the means of a factor was consistent with non-normality of the corresponding distributions for within one, two and three standard deviations of the means. For the factor of media richness, $100 \%$ of the evaluations by all students, female students, male students, and Web sites fell within three standard deviations of the evaluation means, which was not the finding for any other factor. The percentage of evaluations for media richness that fell within one and two standard deviations approximated the normal distribution with $69.26 \%$ and $97.41 \%$ by all students and with $72.14 \%$ and $95.00 \%$ by female students. The lowest percentage of evaluation that fell within one standard deviation of the means was $37.04 \%$ with product selection on site \#3 with all students. The second lowest percentage was $51.54 \%$ with control and freedom with male students.

The frequency distributions summarized in Figure 3 were found to have combined relative frequencies on accessibility and convenience of $74.07 \%$, availability of information of $72.59 \%$, lack of sociality of $77.04 \%$, product selection of $72.22 \%$, and control and freedom of $80.37 \%$ on evaluations of 4.00 (highly helpful) and 3.00 (frequently helpful) with overall students. Distributions had media richness of $69.26 \%$ on evaluations of 3.00 and 2.00 (helpful) with also overall students. Richness had higher evaluations of 2.00 (helpful) and 3.00 (frequently helpful) than any other factor, followed by 1.00 (somewhat helpful) and 4.00 (highly helpful), as the other factors had the highest 4.00 and 3.00 assigned to the them, and as indicated in Table 1 richness had the lowest average evaluation by students, similar to the study of the American Web sites. This suggests that the students in this study did not find media richness to be as helpful as the other factors in goal-focused shopping. The helpfulness across the central 3.00 (frequently helpful) and 2.00 (helpful) ratings followed by the 1.00 (somewhat helpful) and 4.00 (highly helpful) ratings hints to an approximately normal distribution from media richness. For overall frequency distribution, ratings of media richness of 3.00 and 2.00 accounted for the combined frequency of $69.26 \%$. Corresponding indices with female students and male students were similar with all students.

Note: The horizontal axis displays the rating scale for each of the evaluation factors, and the vertical axis displays the frequency of the occurrence of each rating, which is the total number of responses selected by each student for the ratings totaled over the $10 \mathrm{Web}$ sites of the study.

Rating Scale: (0) - Not at All Helpful in Intention to Buy, (1) - Somewhat Helpful, (2) - Helpful, (3) - Frequently Helpful, (4) - Highly Helpful, and (5) - Very Helpful 


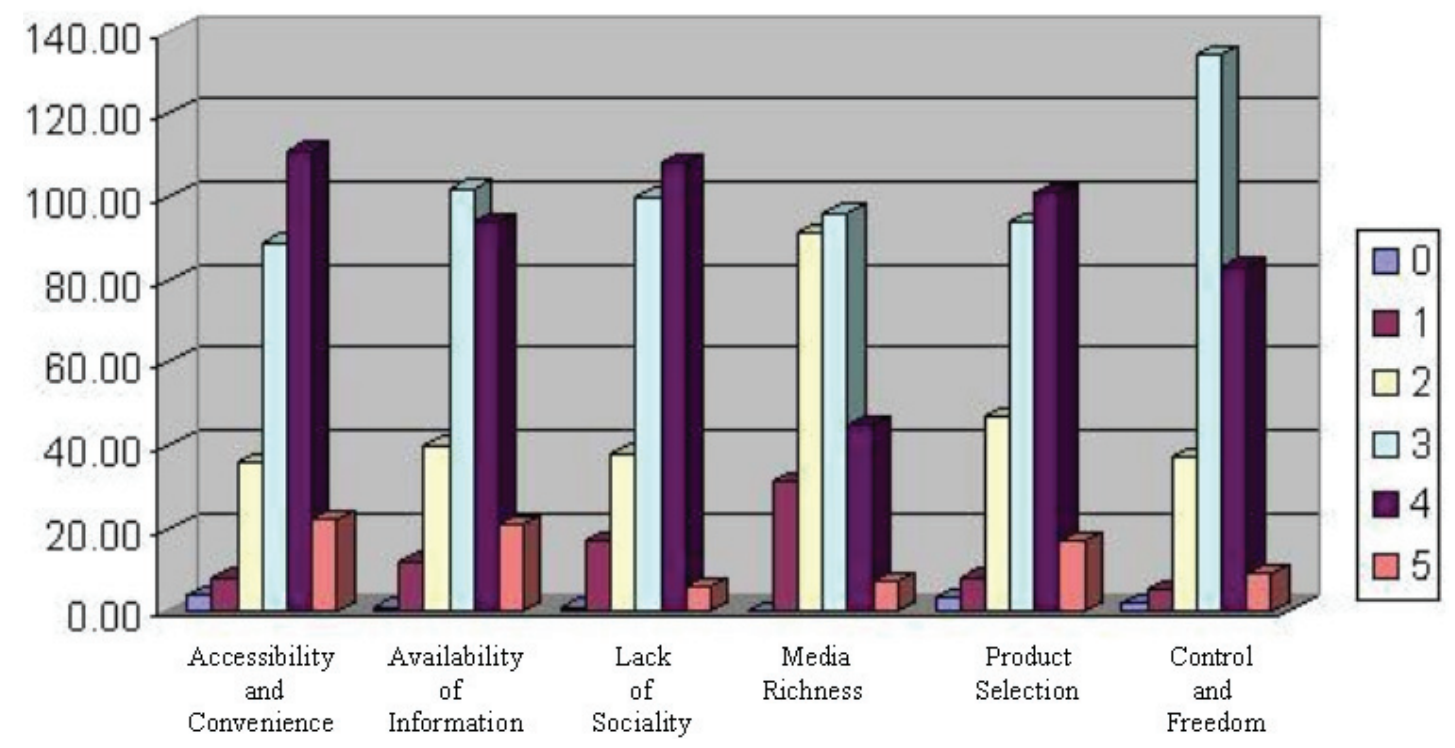

Figure 3: Frequency Distributions of Evaluation Factors - Summary

Finally, the correlation between any pairs of factors was not strong in the study. The correlation between the pairs of factors ranged from 0.158 between media richness and accessibility and convenience to 0.431 between media richness and control and freedom in Table 3. Media richness was associated with the weakest correlation values of 0.158 and 0.159 relative to accessibility and convenience and product selection respectively and of $0.289,0.209$, and 0.431 respectively to availability of information, lack of sociality and control and freedom relative to any other factor.

In the instances where the correlation between media richness and availability of information and media richness and control and freedom were the second weakest for availability of information and control and freedom relative to any other factor, the relationship of availability of information and control and freedom with lack of sociality showed the weakest correlation values of 0.228 and 0.418 respectively for these factors.

Though most of the correlation coefficient values were generally weak, they were significant at the 0.01 level, when they were compared to the null hypothesis of zero correlation, which is similar to the study of the American Web sites. This suggests that there is a linear correlation between each pair of factors. Moreover, the strength of the correlation values is only indicative of the level of linear relationship between pairs of factors. Therefore, some of the weak correlations may be suggestive of stronger non-linear relationships between pairs of factors. With this in mind, it can be stated that the generally weak correlation between media richness and the other factors seems to have resulted from the preference of the students for the non-richness factors of accessibility and convenience, availability of information, lack of sociality and product selection on the Web sites.

With a correlation matrix the small sample size ( $n=27$ students) of the study may be noted to be a significant advantage, inasmuch as the statistical significance of the correlation coefficients in Table 3 was real, not an artifact of the huge sample sizes of studies. 
Table 3: Correlation Matrix of Evaluation Factors

\begin{tabular}{|c|c|c|c|c|c|c|}
\hline \multicolumn{7}{|c|}{ Summary of Evaluation Factors: Correlation Matrix } \\
\hline $\begin{array}{c}\text { Accessibility } \\
\text { and } \\
\text { Convenience }\end{array}$ & $\begin{array}{c}\text { Availability } \\
\text { of } \\
\text { Information }\end{array}$ & $\begin{array}{c}\text { Lack } \\
\text { of } \\
\text { Sociality }\end{array}$ & $\begin{array}{c}\text { Media } \\
\text { Richness }\end{array}$ & $\begin{array}{c}\text { Product } \\
\text { Selection }\end{array}$ & $\begin{array}{c}\text { Control } \\
\text { and } \\
\text { Freedom }\end{array}$ \\
\hline $\begin{array}{c}\text { Accessibility } \\
\text { and } \\
\text { Convenience }\end{array}$ & 1.000 & 1.000 & & & & \\
\hline $\begin{array}{c}\text { Availability } \\
\text { of } \\
\text { Information }\end{array}$ & 0.396 & 0.228 & 1.000 & & & \\
\hline $\begin{array}{c}\text { Lack } \\
\text { of } \\
\text { Sociality }\end{array}$ & 0.305 & 0.289 & 0.209 & 1.000 & & \\
\hline $\begin{array}{c}\text { Media } \\
\text { Richness }\end{array}$ & 0.158 & 0.332 & 0.174 & 0.159 & 1.000 & \\
\hline $\begin{array}{c}\text { Product } \\
\text { Selection }\end{array}$ & 0.303 & 0.530 & 0.418 & 0.431 & 0.545 & 1.000 \\
\hline $\begin{array}{c}\text { Control } \\
\text { and } \\
\text { Freedom }\end{array}$ & 0.547 & & & & & \\
\hline
\end{tabular}

Note: Correlation between any two pairs of evaluation factors is significant at the 0.01 level when compared to the null hypothesis of zero correlation.

In summary, media richness had the lowest mean rating and higher 1.00 (somewhat helpful) and 2.00 (helpful) ratings than accessibility and convenience, availability of information, lack of sociality, product selection, and control and freedom. This mean is statistically different from the respective mean values of the other factors. Because of the general pattern of 2.00 and 3.00 (frequently helpful) ratings and also 1.00 and 4.00 (highly helpful) ratings in its overall, male and female frequency distributions, richness more closely approximated a normal distribution than any other factor. Moreover, since the other factors were skewed to the left because of their higher number of 3.00 and 4.00 ratings, their relationship with media richness tends to be generally weaker. The approximate normal distribution of richness suggests that its mean value is approximately the same as the mean for the population of the original 150 European apparel sites selected in stage 1 of our methodology.

Though the findings of higher helpfulness in accessibility and convenience (mean $=3.34$ ), availability of information (3.26), lack of sociality (3.17), product selection (3.23) and control and freedom (3.18) than in media richness (2.65) on the Web sites are exploratory and preliminary, they furnish information for discussion.

\section{Discussion}

"Perfecting [a] critical mix of content, design and delivery is [needed] in firms ... [Firms] spend ... more time on ... design and delivery ... than on content ... [Firms] focus more ... on aesthetics and technology than on [the] content ... [of their Web sites]" (Scott, 2005).

Limited importance of media richness $($ mean $=2.65)$ as a factor in the intention of the shoppers to buy on the evaluated sites is an implication of the study. Media richness was evaluated by the student subjects as less important and lower, from the fundamental non-richness factors of product selection, lack of sociality, availability of information and accessibility and convenience, even on sites evaluated highly helpful by the students. Given the global growth of streaming-media to 
approximately $\$ 300$ million in 2005 (Top, 2006), firms may have to consider the fruitfulness of investment in media technologies. They may have to further ensure that media technologies do not detract excessively from helpful information on the products marketed on sites or from usability of sites (Rust, Thompson, \& Hamilton, 2006). Study is indicating media rich technologies have to be focused on optimizing the buying processes of shoppers on the European Web.

Further implications include the apparently limited importance of accessibility and convenience $($ mean $=3.34$ / 5.00), availability of information (3.26), lack of sociality (3.17) and product selection (3.23) as non-richness factors helpful in the decision of the goal-focused shoppers to buy on the sample of European sites. Control and freedom (3.18) in the buying of the Belgian students was frequently inhibited by the designs of most of the sites, which, except for lack of sociality, contributed to evaluations of the non-richness factors on the European sites that were generally lower than the evaluations of the American students on accessibility and convenience (3.96), availability of information (3.76), product selection (3.38) and control and freedom (3.63) on the American sites (Lawler \& Joseph, 2006). Designs were generally limited in detailed information on the products and in functional interaction with equipped on-line service or sales staff on the sites (Massad, Heckman \& Crowston, 2006).

Most of the sites in this study were not optimized in a professional design (Fogg, 2003) for linking functionality, information and interaction (Dignan, 2006) to buying judgments by the goalfocused subjects. Though the factors of accessibility and convenience, availability of information, lack of sociality and product selection were helpful in intention to buy on the sites, they were mediocre in importance. Study is indicating improved focusing on fundamental e-Business design innovation may be more beneficial for managers of European firms competing on the Web.

The findings on the relative helpfulness of media richness replicate those in our earlier study of dress model sites in the United States, which had a larger sample size of 68 students in contrast to the 27 students in this study.

Though the evaluation of the Belgian students on the helpfulness of media richness ( mean $=2.65$ ) was slightly higher than the evaluation of the American students on richness (mean $=2.33$ ), the overall frequency distribution of media richness in both studies had the lowest combined highly helpful (4) and very helpful (5) ratings of any evident factor, indicating that the student shoppers did not find this factor highly helpful or very helpful in their goal-focused shopping. In the study of American sites, media richness had a higher number of not at all helpful (0) and somewhat helpful (1) ratings than helpful (2) ratings, though its distribution did not approximate normal as in this study. Nevertheless, the correlation values associated with media richness were generally similar in both studies.

In summary, this study of European dress model sites continues to furnish evidence that the factor of media richness is not as helpful or as important as the non-richness factors of accessibility and convenience, availability of information, lack of sociality and product selection in the intent of goal-focused shoppers to buy apparel on Web sites, and that the non-richness factors may be more helpful on the sites.

\section{Conclusion}

The current study is positioned as an exploratory one, which is attempting to extend findings on factors that impact experiences of shoppers on European Union dress model and picture sites. The generalizability of an experiment consisting of a small homogeneous group of scholar students in one course and of a small number of Web sites has to be considered cautiously. Choice of students biases implications in the context of a general consumer population, which includes diversity for models of mid-aged and older aged subjects. Internet connectivity of a general 
population, which may lack faster connectivity of students benefiting from the laboratory of a university, has to be considered in a future study.

An exhaustive field experiment of further sites, which includes random statistical sampling of non-student subjects and integrated structured interviewing of the subjects, has to be considered for explicit hypotheses. Other factors as price and security may have to be evaluated in a study. The impact of cultural factors (McCracken, 1986) on shopping on the Web sites, specific to countries of study (Mahmood, Bagchi, \& Ford, 2004), may have to be evaluated by researchers, and such a study may evaluate Eastern and Western European countries and segmented subjects.

Future study will continue in a larger field experiment, dependent on governmental and academic funding, and which will include non-student and student subjects.

This study of European goal-focused shoppers on European Union dress model sites is beginning to contribute deeper insight into the criticality of differential design factors. Consumer acceptance of technology continues to be a complex if not an elusive challenge for European firms competing on the Web. Fundamental functionality of accessibility and convenience, availability of information, lack of sociality and product selection is suggested to be more important than media richness of advanced technology in the intention of shoppers to buy on the European sites, replicating the results of our study of dress model sites in the United States. As firms in the European Union continue to evaluate rich technologies on their Web sites, they may be guided in the apparent impact of the technologies by the preliminary results of the study. Further refinement of the results of this study is welcome by the authors, as the current analysis evolves in a larger research study of European dress model sites in 2007 and 2008.

\section{Acknowledgements}

The authors are grateful to Bernard Lux, President of the University of Mons-Hainaut, and to the National Fund for Scientific Research, Brussels, Belgium, for the funding of this study in 2006 and 2005. They are also grateful to the e-Business students of the University of Mons-Hainaut who diligently helped in the laboratory experiment of the study, under the supervision of the second author. This study was initiated when the first and principal author was a visiting professor at the University of Mons-Hainaut in spring 2006 and 2005.

\section{References}

Applegate, R. (1993). Models of user satisfaction: Understanding false positives. Reference Quarterly, 32, 525-539.

Baudouin, N. \& Kara, S. (2006, May 1). European retail: Slow growth in store. Business Week, 1, pp. 1-2.

Bergadaa, M. \& Hebali, M.J. (2001). From the tool to the virtuality: Motivation and styles of internet users: The example of seniors. Journal of Euromarketing, 11 (2), 41-69.

Biocca, F. (1997). Cyborg's dilemma: Progressive embodiment in virtual environments. Journal of Computer-Mediated Communication, 3 (2).

Brown, S.A., Massey, A.P., Montoya-Weiss, M.M., \& Burkman, J.R. (2002). Do I really have to? User acceptance of moderated technology. European Journal of Information Systems, 11 (4), 283.

Caudron, M. (2006). Snap judgments. Communications of the ACM, 49 (3), 9.

Celsi, R.L. \& Olson, J.C. (1988). The role of involvement in attention and comprehension processes. Journal of Consumer Research, 15, 210-224. 
Chen, H-M, Chen, Q. \& Kazman, R. (2007). The affective and cognitive impacts of perceived touch on online customers' intention to return in the web-based e-crm environment. Journal of Electronic Commerce in Organizations, 5 (1), 3.

Cronin, M.J. (1995). Doing more business on the Internet. New York: Van Nostrand Reinhold.

Davis, F.D. (1989). Perceived usefulness, perceived ease of use, and user acceptance of information technology. MIS Quarterly, 13 (3), 319-340.

DeVore, J. (1995). Probability and statistics for engineering and the sciences. New York: Duxbury Press.

Dignan, Larry (2006, November 13). On-line experience: Content housecleaning. e-Week, p. 46.

European Commission. (2005a). The European e-business report 2005. European Commission: Enterprise \& Industry Directorate General, November, 12.

European Commission. (2005b). A pocketbook of e-business indicators. European Commission: Enterprise \& Industry Directorate General, May, 8,14.

Ewing, J. (2006, June 5). Otto the modest: The German retailer is a powerhouse in worldwide sales, but it is not blowing any flugelhorns. Business Week, p. 44.

Fiore, A.M. \& Jin, H-J. (2003). Influence of image interactivity on approval responses towards an on-line retailer. Internet Research: Electronic Networking Applications \& Policy, 13 (1), 39, 44.

Fisher, J. (1999). Improving the usability of information systems: The role of the technical communicator. European Journal of Information Systems, 8 (4), 294-299.

Fogg, B.J. (2003). Stanford guidelines for web creditability. Persuasive Technology Lab, Stanford University, November.

Hemp, P. (2006, June). Avatar-based marketing. Harvard Business Review, pp. 48-57.

Hoffman, D.L. \& Novak, T.P. (1996). Marketing in hypermedia computer-mediated environments: Conceptual foundations. Journal of Marketing, 60 (3), 50-68.

Horyn, C. (2005, December 15). Point, click and strut. The New York Times, p. 3.

Jana, Reena (2006, July 10). Shop till your avatar drops. Business Week, p. 12.

Jarvenpaa, S.L. \& Todd, P.A. (1997). Consumer reactions to electronic shopping on the world wide web. International Journal of Electronic Commerce, 1 (2), 59-88.

Jones, G. (2006, , May 8). Five technologies you need to know about. ACM TechNews, p. 11.

Klein, L.R. (2003). Creating virtual product experiences: The role of telepresence. Journal of Interactive Marketing, 17 (1), 41-54.

Koo, C.M., Koh, C.E., \& Nam, K. (2004). An examination of Porter's competitive strategies in electronic virtual markets: A comparison of two on-line business models. International Journal of Electronic Commerce, 9 (1), 166.

Koufaris, M. (2002). Applying the technology acceptance model and flow theory to on-line consumer behavior. Information Systems Research, 13 (2), 206.

Lawler, J. \& Joseph, A. (2006). A study of apparel dress model technology on the web. Journal of Information, Information Technology, and Organizations, 1, 59-73. Available at http://jiito.org/articles/JIITOv1p059-073Lawler20.pdf

Levinson, M. (2006, March 1). Flash in the on-line plan: Rich internet technologies can make your web site more engaging for customers and more profitable for you. $C I O, 58$.

Li, H., Daugherty, T., \& Biocca, F. (2001). Characteristics of virtual experience in electronic commerce: A protocol analysis. Journal of Interactive Marketing, 15 (3), 13-30.

Lightner, N.J. (2004). Evaluating e-commerce functionality with a focus on customer service. Communications of the ACM, 47 (10), 88. 
Lynch, J. \& Ariely, D. (1998). Interactive home shopping effects of search cost for price and quality information on consumer price sensitivity, satisfaction with merchandise selected, and retention. Paper, Duke University.

Lynch, P.J. \& Horton, S. (1999). Web style guide: basic design principles for creating web sites. New Haven, Connecticut: Yale University Press.

Mahmood, M.A., Bagchi, K., \& Ford, T.C. (2004). On-line shopping behavior: Cross-country empirical research. International Journal of Electronic Commerce, 9 (1), 24.

Massad, N., Heckman, R., \& Crowston, K. (2006). Customer satisfaction with electronic service encounters. International Journal of Electronic Commerce, 10 (4), 73, 96-97.

McClave, J. \& Sincich, T. (2006). A first course in statistics. Upper Saddle River, New Jersey: Prentice Hall.

McCracken, G. (1986). Culture and consumption: A theoretical account of the structure and movement of the cultural meaning of consumer goods. Journal of Consumer Research, 13, 71-84.

Moe, W.W. \& Fader, P.S. (2001). Uncovering patterns in cyber-shopping. California Management Review, $43(4), 114$.

Nielsen, J. (2002). Usable information technology. Available at http://www.useit.com

Ohmae, K. (2005). The next global stage: Challenges and opportunities in our borderless world. Upper Saddle River, New Jersey: Wharton School Publishing, 176-177.

Patton, S. (2006, June 1). Answering the call. CIO, pp. 75-80.

Peterson, S. (2006, February, 10). Spectrum: Euro-divide. Government Technology.

Rust, R.T., Thompson, D.V., \& Hamilton, R.W. (2006, February). Defeating feature fatigue. Harvard Business Review, 84 (2), 2.

Saeed, K.A., Hwang, Y., \& Grover, V. (2003). Investigating the impact of web site value and advertising on firm performance in electronic commerce. International Journal of Electronic Commerce, 7 (2), 119-141.

Scott, D.M. (2005). Cashing in with content: How innovative marketers use digital information to turn browsers into buyers. Medford, New Jersey: Information Today, 239.

Spector, R. (2005). Category killers: The retail revolution and its impact on consumer culture. Boston, Massachusetts: Harvard Business School Press, 62.

Top, D. (2006, March). Incubator: Innovation and entrepreneurship: \$298 million. Optimize, 17.

Urban, G., Carter, T., Gaskin, S., \& Mucha, Z. (1986). Market share rewards to pioneering brands: An empirical analysis and strategic implications. Management Science, 32 (6), 645-659.

Venkatesh, V. \& Davis, F.D. (2000). A theoretical extension of the technology acceptance model: Four longitudinal field studies. Management Science, 46 (2), 187.

Venkatesh, V., Morris, M., Davis, G., \& Davis, F. (2003). User acceptance of information technology: Toward a unified view. MIS Quarterly, 27 (3), 425-478.

Wolfinbarger, M. \& Gilly, M.C. (2001). Shopping on-line for freedom, control, and fun. California Management Review, 43 (2), 34-55. 


\section{Appendix}

European Dress Model and Picture Sites of Study: Analysis of Evaluation Factors-Detail

\begin{tabular}{|c|c|c|c|c|c|c|}
\hline & $\begin{array}{c}\text { Accessibility and } \\
\text { Convenience }\end{array}$ & $\begin{array}{c}\text { Availability } \\
\text { of Information }\end{array}$ & $\begin{array}{c}\text { Lack } \\
\text { of } \\
\text { Sociality }\end{array}$ & $\begin{array}{l}\text { Media Rich- } \\
\text { ness }\end{array}$ & $\begin{array}{l}\text { Product } \\
\text { Selection }\end{array}$ & $\begin{array}{c}\text { Control } \\
\text { and } \\
\text { Freedom }\end{array}$ \\
\hline \multicolumn{7}{|l|}{ Site \#1 } \\
\hline Mean & 3.56 & 3.41 & 3.19 & 2.41 & 3.30 & 3.04 \\
\hline $\begin{array}{l}\text { Standard } \\
\text { Deviation } \\
\end{array}$ & 0.93 & 0.89 & 0.96 & 0.69 & 0.99 & 1.09 \\
\hline \multicolumn{7}{|l|}{ Site \#2 } \\
\hline Mean & 3.52 & 3.07 & 3.37 & 2.78 & 3.07 & 3.19 \\
\hline $\begin{array}{l}\text { Standard } \\
\text { Deviation }\end{array}$ & 0.85 & 0.73 & 0.56 & 0.70 & 1.04 & 0.56 \\
\hline \multicolumn{7}{|l|}{ Site \#3 } \\
\hline Mean & 3.67 & 3.63 & 3.11 & 2.59 & 3.19 & 3.37 \\
\hline $\begin{array}{l}\text { Standard } \\
\text { Deviation } \\
\end{array}$ & 1.00 & 0.93 & 0.89 & 0.84 & 0.79 & 0.79 \\
\hline \multicolumn{7}{|l|}{ Site \#4 } \\
\hline Mean & 2.81 & 3.22 & 3.11 & 2.74 & 2.74 & 2.85 \\
\hline $\begin{array}{l}\text { Standard } \\
\text { Deviation }\end{array}$ & 1.14 & 1.09 & 1.05 & 0.90 & 1.40 & 1.03 \\
\hline \multicolumn{7}{|l|}{ Site \#5 } \\
\hline Mean & 2.96 & 2.85 & 3.00 & 2.44 & 3.15 & 2.96 \\
\hline $\begin{array}{l}\text { Standard } \\
\text { Deviation } \\
\end{array}$ & 1.02 & 0.95 & 1.00 & 0.97 & 0.86 & 0.59 \\
\hline \multicolumn{7}{|l|}{ Site \#6 } \\
\hline Mean & 3.44 & 3.37 & 2.96 & 2.52 & 3.74 & 3.30 \\
\hline $\begin{array}{l}\text { Standard } \\
\text { Deviation } \\
\end{array}$ & 1.19 & 1.11 & 1.19 & 1.01 & 0.86 & 0.87 \\
\hline \multicolumn{7}{|l|}{ Site \#7 } \\
\hline Mean & 3.15 & 3.04 & 3.22 & 2.67 & 3.22 & 3.04 \\
\hline $\begin{array}{l}\text { Standard } \\
\text { Deviation } \\
\end{array}$ & 0.95 & 1.22 & 1.01 & 0.83 & 0.97 & 0.52 \\
\hline \multicolumn{7}{|l|}{ Site \#8 } \\
\hline Mean & 3.00 & 3.15 & 2.89 & 2.59 & 3.11 & 3.04 \\
\hline $\begin{array}{l}\text { Standard } \\
\text { Deviation } \\
\end{array}$ & 0.92 & 1.03 & 1.05 & 1.15 & 0.97 & 0.90 \\
\hline \multicolumn{7}{|l|}{ Site \#9 } \\
\hline Mean & 3.81 & 3.50 & 3.46 & 3.35 & 3.27 & 3.58 \\
\hline $\begin{array}{l}\text { Standard } \\
\text { Deviation }\end{array}$ & 0.75 & 0.58 & 0.81 & 1.09 & 0.78 & 0.86 \\
\hline \multicolumn{7}{|l|}{ Site \#10 } \\
\hline Mean & 3.44 & 3.30 & 3.33 & 2.41 & 3.56 & 3.41 \\
\hline $\begin{array}{l}\text { Standard } \\
\text { Deviation }\end{array}$ & 0.89 & 0.99 & 0.73 & 1.19 & 0.85 & 0.75 \\
\hline
\end{tabular}

Note: Results on the sites are indicated by numbers, in order to ensure confidentiality of the firms. 


\section{Biographies}

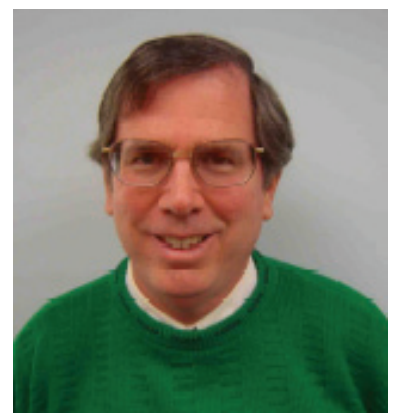

Dr. James Lawler, Principal Author, is Associate Professor of Information Systems, in the Information Systems Department, of The Ivan G. Seidenberg School of Computer Science and Information Systems, at Pace University, in New York City, USA. His interests in research include competitive e-Commerce Web design methods and eCommerce and customer relationship management (CRM) technologies on the Web, in the United States, Europe and northern Africa. He is a Visiting Professor of Information Systems, at the University of Mons-Hainaut, in Mons, Belgium.

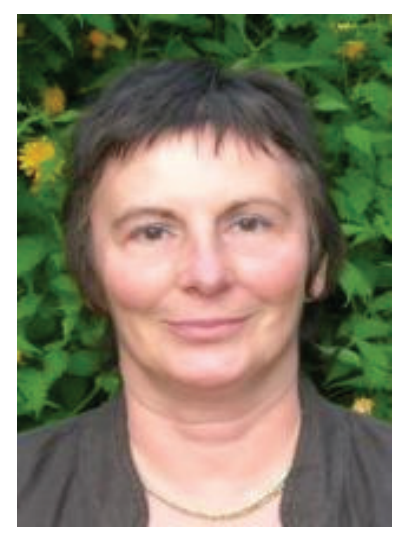

Dr. Pascale Vandepeutte is Lecturer of Computer Science and eBusiness, at the University of Mons-Hainaut, Mons, Belgium. Her interests in research include e-Commerce methodologies and mobile computing and privacy regulations and technologies in the European Union. She is a frequent collaborator with Dr. Lawler on e-Commerce research in Europe and northern Africa.

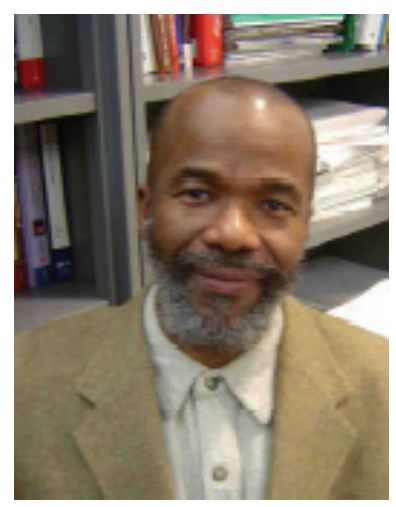

Dr. Anthony Joseph is Associate Professor of Computer Science, in the Computer Science Department, of the Seidenberg School, at Pace University, New York. His interests in research include digital signal processing techniques in spectral and time-frequency studies and active learning and collaborative learning techniques. He is a frequent collaborator with Dr. Lawler and Dr. Vandepeutte on research and on statistical techniques. 